\title{
Integrating Crisis Management into the Strategic Planning Process in the Service Sector Firms
}

\section{Mohammed Waleed Mudalal}

To Link this Article: http://dx.doi.org/10.6007/IJARAFMS/v11-i3/11616 DOI:10.6007/IJARAFMS /v11-i3/11616

Received: 21 July 2021, Revised: 25 August 2021, Accepted: 05 September 2021

Published Online: 28 September 2021

In-Text Citation: (Mudalal, 2021)

To Cite this Article: Mudalal, M. W. (2021). Integrating Crisis Management into the Strategic Planning Process in the Service Sector Firms. International Journal of Academic Research in Accounting Finance and Management Sciences, 11(3), 740-761.

Copyright: @ 2021 The Author(s)

Published by Human Resource Management Academic Research Society (www.hrmars.com)

This article is published under the Creative Commons Attribution (CC BY 4.0) license. Anyone may reproduce, distribute, translate and create derivative works of this article (for both commercial and non-commercial purposes), subject to full attribution to the original publication and authors. The full terms of this license may be seen

at: http://creativecommons.org/licences/by/4.0/legalcode

Vol. 11, No. 3, 2021, Pg. 740 - 761

Full Terms \& Conditions of access and use can be found at http://hrmars.com/index.php/pages/detail/publication-ethics 


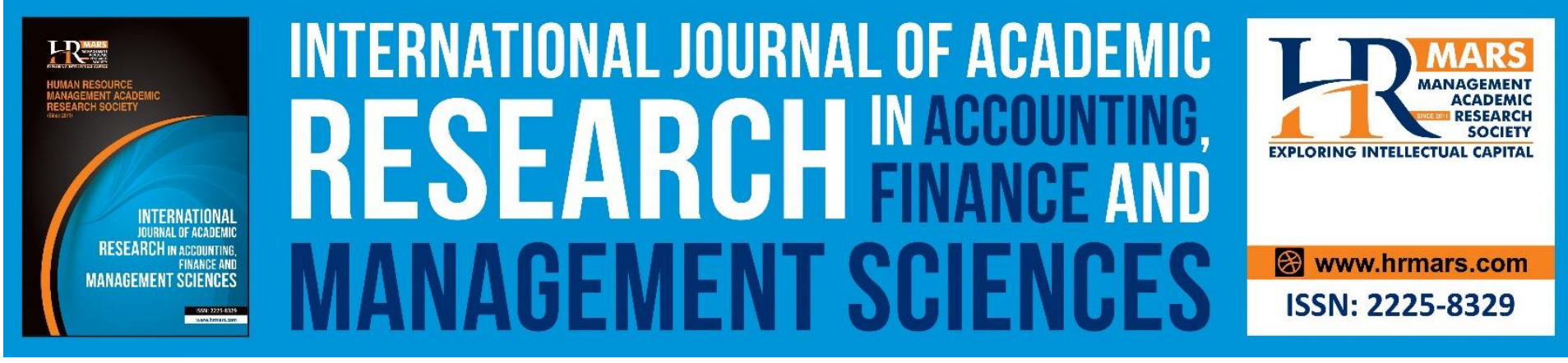

\title{
Integrating Crisis Management into the Strategic Planning Process in the Service Sector Firms
}

\author{
Mohammed Waleed Mudalal \\ Azman Hashim International Business School, Universiti Teknologi Malaysia, 81310, Skudai, \\ Johor, Malaysia \\ Email: mohwaleed1984@gmail.com
}

\begin{abstract}
The purpose of this study is to investigate the integration of crisis management into the strategic planning process. So, by understanding this integration in the time of crises, the service sector firms could strategically deal with challenges and uncertainties. In fact, this orientation can professionally supply firms with a defensive capability for preventing crises growth or lessening their effects. The qualitative method was used for analyzing the semi structured-interviews that were conducted by senior managers who were selected from top management. Findings were empirically supported according to the study respondents who confirmed that adding the crisis management concept to the strategic planning processes, will make those processes more effective and eligible in times of crisis. Basically, the integration of crisis management into strategic planning can give a more inclusive approach to the strategic planning process, which seems to fundamentally promote the strategist's work. This paper deepens the theoretical understanding of the consequences of strategy process.
\end{abstract}

Keywords: Strategy, Crisis Management, Strategic Planning, Integration, Service Sector Firms

\section{Introduction}

The fields of both concepts, strategic planning and crisis management have been developing individually despite their potential for cohesive incorporation. This paper explains how combining crisis management capability with the strategic planning position orientation, can enhance their ability to survive and thrive in the time of crises. Recently, many scholars have attempted to explore the common ground between these domains and have concluded that crisis management and strategic planning are inevitably linked to each other (Vargo \& Seville, 2011; Pollard, 2008; Preble, 1997; Mitroff et al., 1992). However, the nature of these linkages is just beginning to be specified, integration into the usual strategic planning process still not yet adopting this connection. So the aim of this paper is to show how integrating crisis management into the strategic planning process can grant firms defensive capabilities for preventing crises or diminishing their effects (Preble, 1997).

In today's competitive environment, business has become more complex and challenging, so any business large or small that is not managed strategically well is very vulnerable (Nickols, 2016; Ocloo et al., 2014). Therefore, firms have to put in place the correct strategies and apply 
MANAGEMENT SCIENCES

Vol. 11, No. 3, 2021, E-ISSN: 2225-8329 @ 2021 HRMARS

these strategies in order to embrace the unstable situations (Ocloo et al., 2014). Crisis Management is viewed as a strategic process in firms that it effectively identifies the crises and professionally manages them, taking into account each step of the planning activities to deal professionally with crises. Crisis management is the direction of preparing the resources and the organizational structures in order to respond efficiently in the face of a crisis and recover well in the aftermath. It is about establishing the capability to identify coming threats to the firm and designing a plan for addressing those threats. (Vargo \& Seville, 2011)

Strategic planning cares about the mid-term future of the firm, developing its success by dealing with weaknesses, threats, strengths and opportunities in firms. It is about selecting a range of strategies and building a plan to implement those strategies, including arranging the resources and organizational elements to carry out the plan and assess its performance (Preble, 1997). It is clear from these two definitions that they both frequently: deal with the future, deal with weaknesses and threats, involve in creating a plan, and engage with organizational structures and resources.

The focus of this study is on integrating crisis management into the strategic planning process through exploring the common characteristics of the two concepts in the Palestinian service sector firms. Accordingly, the following main question was developed:

- How can crisis management be integrated into the strategic planning process?

The two significant secondary questions were then developed to further follow the answer to this general question, as follows:

- How crisis management works in the strategic planning process in GEDCO?

- Who are the main influencers in the strategic process?

In order to attain a better understanding of this integration, a case study was employed in the Gaza Distribution Electricity Company in Palestine called and 8 managers were selected from top management of the company (board of directors, GM of the company, senior manager of strategic planning department, manager of HR department, manager of public relations department, manager of financial department, manager of corporate communications department). Those respondents were selected using quota sampling technique. They were considered suitable for studying the exact manner in which to model essential details within the strategy process.

It is worth mentioning that the crisis management is a big issue to GEDCO to be always involved in the strategic planning processes of the company. The company has been experiencing internal and external crises and continues to confront crises. The biggest crisis currently in Gaza strip is in the service sector, specifically in electricity supply, and this company is responsible for distributing power to several areas in Gaza Strip using strategies for this distribution, in addition to using practical strategies for dealing with crises or minimizing their effects. Furthermore, the company has to be more flexible in facing crises as it needs to direct a set of apparent flaws that put together effective planning with adaptability to changing situations including having leaders with the ability to inspire people with a sense of hope and direction, to have an organizational culture that values controlled planning whilst developing innovation, to plan and make decisions wisely and structured effectively yet to be responsive and approachable (Alsharif et al., 2021a, 2021c). Finally, the company has to be guided by a strategic process for the internal and external environment in light of the vision, mission and clear objectives. It is in a dire need to have a strategic plan considered as a strong shield protecting it from internal or external crises. 
MANAGEMENT SCIENCES

Vol. 11, No. 3, 2021, E-ISSN: 2225-8329 @ 2021 HRMARS

\section{Literature Review}

Based on previous studies, (Vargo \& Seville, 2011; Preble, 1997; Mitroff et al., 1992) argued that crisis management is strategic in nature and it should be integrated into strategic planning as they both share much of common characteristics, particularly in coping the internal and external crises. As well, Tony Jaques (2010) claimed that to help avoid such organizational crises, leaders need to incorporate crisis management into the strategic planning process in order to make sure a no-fault environment to encourage reporting of possible failures and errors and be prepared to willingly accept bad news and unusual results.

Table 1

Prior studies found on the integration of crisis management and strategic planning

\begin{tabular}{|l|l|l|l|}
\hline \multicolumn{2}{|l|}{ Key concepts used in the study } & Situation/Area & Author \\
\hline $\begin{array}{l}\text { Crisis } \\
\text { management }\end{array}$ & $\begin{array}{l}\text { Strategic } \\
\text { management }\end{array}$ & $\begin{array}{l}\text { In the competitive } \\
\text { market- place }\end{array}$ & (Preble, 1997) \\
\hline $\begin{array}{l}\text { Crisis } \\
\text { management }\end{array}$ & Scenario planning & $\begin{array}{l}\text { Transformation } \\
\text { economies of East and } \\
\text { Central Europe }\end{array}$ & (Pollard, 2008) \\
\hline Risk management & Strategic planning & $\begin{array}{l}\text { Perception and reaction } \\
\text { to high level of } \\
\text { uncertainty in banking } \\
\text { industry }\end{array}$ & (Achampong, 2010) \\
\hline $\begin{array}{l}\text { Crisis } \\
\text { management }\end{array}$ & Strategic planning & $\begin{array}{l}\text { Resilience in the time of } \\
\text { crises in SMEs, New } \\
\text { Zealand }\end{array}$ & (Vargo \& Seville, \\
\hline $\begin{array}{l}\text { Enterprise risk } \\
\text { management }\end{array}$ & Strategic planning & $\begin{array}{l}\text { Firms of insurance and } \\
\text { financial sectors }\end{array}$ & (Sax, 2015) \\
\hline Strategic planning & $\begin{array}{l}\text { Crisis } \\
\text { management }\end{array}$ & $\begin{array}{l}\text { Political environment in } \\
\text { Egypt }\end{array}$ & (Karam, 2018) \\
\hline
\end{tabular}

Preble (1997) explicated in his study that the integration of crisis management's defensive capabilities into strategic management's offensive positioning orientation can give a more comprehensive technique to the strategic management. He confirmed that crisis management is a strategic in nature, although some scholars opposed this idea such as (Drabek \& Hoetmer, 1991) claimed that crisis management deals directly with the tactical decisions and actions. Preble also asserted that the strategic planning process resulted in strategies, it presents a strong defense in the competitive marketplace, so this process paid weak attention to defensive actions that could act to prevent unwanted and unexpected crises from happening due to the missing of crisis management in this process to deal effectively with these crises or external effects. To fill this gap, Preble argued that combining crisis management's defensive capability for ending crises or their effects, with the strategic planning's focus on market, will make the strategic planning process more comprehensive and effective. He concluded that a strategic management process which does not strive for high reliability and crisis preparedness is no SM process at all, and is useless.

The general aim of the study of Pollard (2008) is to assess the significance of undertaking proactive crisis management in the setting of the strategy process within firms located in East and Central Europe. It is argued that firms can obtain major advantages by preparing for 
MANAGEMENT SCIENCES

Vol. 11, No. 3, 2021, E-ISSN: 2225-8329 @ 2021 HRMARS

emergencies in advance, and integrating them into the strategic management process. The presence of a crisis management plan is necessary but not adequate, as there is a danger that organizations ignore the warning signs or causes of a future crisis through over-dependence on the plan. In Pollard's study, the concept of strategic management and crisis management lacked empirical content, so this lack limited the development of knowledge in this fundamental area. Considerably, the current crisis management literature covers one further gap in the context of drawing attention to the significance of external actions in the management of crises, such as, the role of the media (Pollard (2008). Therefore, further research into the integration and common areas of analysis is required. On that basis, this study is considered as an expansion for more development in theoretical and practical perspectives.

In the study of Achampong (2010), the integration of the activities of strategic planning and risk management into one harmonized and comprehensive process is both rational and needed in order to create an interactive effect that influences the benefits of both processes and makes them mutually supporting. This incorporation also united the efforts of strategic planning and risk management committees in achieving the strategic planning aims that belong to developing the financial strength of a firm and finally fulfill its desired vision. Reviewing Achampong's perspective, it was found that the result of his study agreed with the finding of this study in this regard. Furthermore, the incorporation of risk management and strategic planning must be supported by top administration. More importantly, the recommendation of this study was also sought by this study such as: a firm can incorporate its risk management into its strategic plan by involving it under proper planning goals, determining appropriate tactics, and assigning responsibility for the risk management objectives. Eventually, special training courses must be offered to members with risk management and to effectively form and carry out the risk management component of the strategic plan.

Vargo \& Seville (2011) clearly confirmed the common characteristics of integrating strategic planning and crisis management, finding the silver lining between the two concepts. Thus, these main concepts, deal with the future, deal with the weaknesses and threats, involve setting a plan, and involve organizational structures to implement the plan. Burnett (1998) in this context recommended seven types of opportunities that may appear in a crisis as a silver lining. First, champions are born; second, changes are increased; third, problems are faced; fourth, people can be changed; fifth, new strategies evolve; sixth, early caution systems are enhanced and finally, seventh, new competitors may arise. Consequently, by integrating crisis management into a firm's strategic planning processes, strategies can be advanced to benefit from these silver lining opportunities during crises. So, the emphasis is typically on incorporating crisis management perspective into the strategic planning process to create more effective planning. Therefore, this study was adopted as it is comprehensively similar to the main idea of this study. Substantially, while some SMEs consider the precautionary measures as a call for action, others remain unprepared to cope with potential crises. Spillan and Hough (2003) found that SMEs focus mainly on those types of crises they have experienced before, underrating the risk of events they have no prior experience. In this respect, (Vargo \& Seville, 2011) go along with this view of taking immediate actions towards possible crises.

Sax (2015) clarified that there is a shortage of knowledge on how the enterprise risk management (ERM) frameworks add value and develop firms' organizational performance. The study determined the theoretical gap in ERM research by presenting evidence that an 
MANAGEMENT SCIENCES

Vol. 11, No. 3, 2021, E-ISSN: 2225-8329 @ 2021 HRMARS

integration of risk management and strategic planning is necessary to attain all of the benefits and possibilities that ERM has to offer. Consequently, much of literature in strategic management has referred to strategic planning as a vital process to firms to strategically manage uncertainty and to ensure that the firm continues to operate in the future with all effectiveness and efficiency. In recent years there has been an accelerating attention of inserting ERM within the strategic management processes. As well, ERM has presented a turn on how firms cope with risks and ERM is increasingly considered as an essential management device that totally evaluates and manages all the risks confronted by a firm. Highlighting the point of integration of risk management and strategic planning is a dire need to gain all benefits and possibilities that ERM has to provide. This result is also sought by the researcher in order to respond to these calls and aims to add to the emerging ERM literature, as well as the strategic management literature, by raising the perception of the relationship between the two concepts.

Lastly, a study which was conducted by Karam (2018) referred to the important role of strategic planning in the time of crises to enhance the hotels' ability in order to survive and thrive in crises, particularly in hospitality industry in the service sector. However the weakness of the management to respond to the impacts of crises, let many countries and big institutions suffer huge pressures and burdens on business. So they are in need to plan and think strategically during a crisis by managing both the positive opportunities and negative threats that crisis constantly presents. Consequently, organizations need to plan for crisis alongside as strategic planning that have not yet been incorporated or integrated. In this context, Karam (2018) claimed that managers who effectively work out the strategic planning activities are less escapable and able to manage the crises either by using the style of cooperation, confrontation or containment. Therefore, hotels should utilize a strategic approach to crisis management by embodying crisis management in the strategic process as an essential and integrated part in strategic planning. Fundamentally, the study of Karam (2018) has strongly recommended future studies to integrate the crisis management perspective into the strategic planning process in order to advance the capability of firms not only to survive but also to prosper.

Based on the above studies, the researcher sought to support the perspective of (Preble, 1997). This study highlighted the main variables presented in the study professionally and in detail. The conclusion of that study was the strategic process which does not contain crisis management perspective is a vulnerable process and need to be protected by this shield and need to be enriched with this concept. Therefore, this study undoubtedly identifies the most important strengths that can be added to the strategic plan, leaving no areas of weaknesses in the face of crises, whether internal or external, especially in economically or politically volatile environments.

Many theories have attempted to explicate strategic planning processes in firms. Literature points out to the better management as a function of strategic planning performed by firms. So the Dynamic Capabilities Theory (DCT) is used in this study (Teece et al., 1997). This theory facilitates the conception of the integration of crisis management into the strategic planning process. DCT focuses on firm competitiveness in inconstant environments. Teece et al. (1997) stated that 'dynamic' refers to a fast changing environment while 'abilities' include internal and external organizational skills, competencies and learning techniques. In this context, Teece et al. (1997) used the term "dynamic capability" to indicate to a firm's capability in order to renew capacities and skills over time to fulfil similarity with external environments. In their contribution, Teece and his colleagues argued that dynamic capabilities theory 
MANAGEMENT SCIENCES

Vol. 11, No. 3, 2021, E-ISSN: 2225-8329 @ 2021 HRMARS

empowers firms to combine, establish, and reconfigure their resources and potentials and thus, keep good performance in the face of uncertain business environments. This theory is the most appropriate theory when searching about strategic processes in volatile environments. In a completely unstable environment, the aspect of dynamic capabilities is viewed to be supportive in developing a framework to realize why some firms succeed or fail to escape and prosper in the time of crises (Kitching et al., 2009). It has been claimed by authors such as Eisenhardt \& Martin (2000) and Bustinza et al. (2010) that dynamic capabilities allow firms to change their resources and strategies to the best and also in coping with the external environment to incorporate, build and form internal and external competencies or skills to quickly address the challenging surroundings. Consequently, it is argued that firms with strong dynamic capabilities are highly risk-taking because they are adapted to the business system and can respond to crises through new innovations (Teece, 2007).

\section{Methodology}

\section{Study Design and Sampling}

The population is the specific group that is considerable for the study project which has the relevant data for the study. Generally, the target population has to be recognized. According to Sekaran (2003) as mentioned previously that the target population refers to a group of people that have the same features and positions. In this study, the high official managerial level which consisted of managers working in GEDCO in Gaza Strip are the target population (MAS, 2015). They were selected as the target population since these positions were considered the main essential levels in the organizational chart especially in regard to influencing the strategic planning process and the extent of their effectiveness in confronting the crises. In fact, they are responsible for the most critical operations and duties in these firms, besides leading the teamwork and most employees in the workplace. Furthermore, they were involved in the direct dealing with the top management in firms such as general managers and consultants.

Significantly, the unit of analysis of this study, was individuals' unit since it measured the perceptions of managers in the service sector firms specifically in the electricity company which is GEDCO. In this context, the study sought to investigate the crisis management perspectives among managers and their influences with integrating crisis management into strategic planning process regarding the service sector firms. Research questions determined the unit of analysis where it was considered as the prime purpose in this study. 
MANAGEMENT SCIENCES

Vol. 11, No. 3, 2021, E-ISSN: 2225-8329 @ 2021 HRMARS

Figure 1 Organizational chart of GEDCO

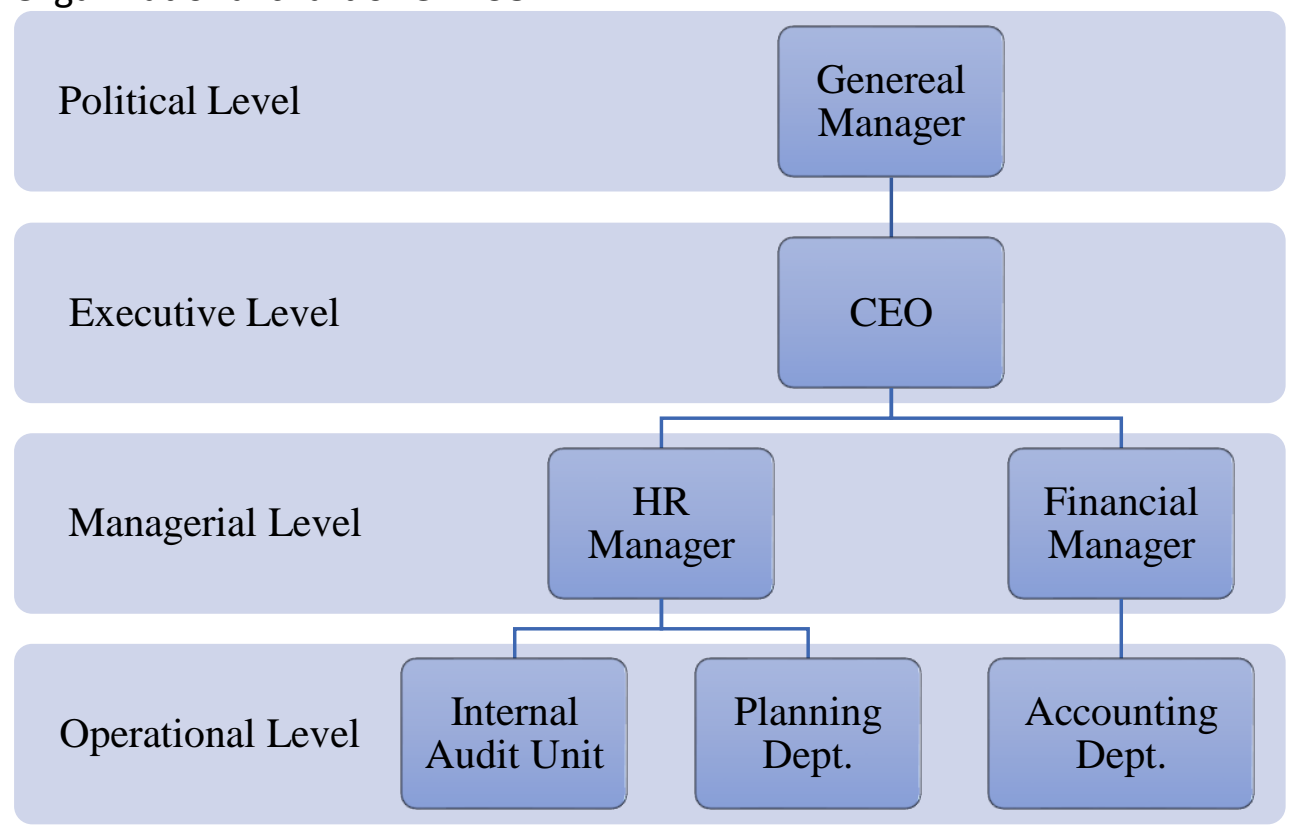

The total population of the study as identified was 120 full time managers working in different units of the company. the questionnaires were translated to Arabic as well as the interviews were transcribed and translated also to Arabic language to be understandable and clear to respondents in order to give correct answers as this will facilitate the process to be properly done.

\section{Sampling Method}

The quota sampling method was used in this study, to conduct the research, authoritative sampling, and a selective or subjective sampling as it is one of the types of non-probability sampling technique. Non-probability sampling concentrates on sampling techniques where the units that are tested based on the judgment of the researcher and the criteria required, if it comes to choosing the units (e.g., people, cases/firms, events, information of data) that are to be under focus. That is, choosing the quota sample was essential to the quality of data collected (Yang \& Banamah, 2014).

Quota sampling can be used to monitor the number of respondents that are allowed to complete a survey based on particular traits like age, gender, race, and location knowledge and practical experience. Additionally, it was possible to use when a limited number of individuals have the same traits of interest. Particularly, when the researcher needs to study a certain cultural domain in social sciences with experts, the quota sampling technique is the most effective technique to be used. The use of quota sampling is acceptable and even necessary. As well, since the researcher has defined the sampling method, the study aims to investigate how management within service sector firms make strategic plans during crises. Basically the researcher divided the target population into subgroups based on some specific known characteristics, traits, or interests, then collected data from identified number of people in those subgroups.

On the other hand, the interview is considered to be the most essential and important qualitative research source because it is a guided conversation rather than structured enquiries (Yin, 2013). So it suggested having descriptions about the actual life of the interviewees in regard to interpretation of the meaning of the phenomena. Moreover, the 
MANAGEMENT SCIENCES

Vol. 11, No. 3, 2021, E-ISSN: 2225-8329 @ 2021 HRMARS

interview provides the opportunity to deeply investigate new information and accordingly opens up new dimensions. So, the interviewer concentrated on the questions on the real-life experiences (Saunders et al., 2009). Normally interviews are used when doing a case study research in qualitative methodology whether it is fully or partially (Hancock \& Algozzine, 2015). The semi-structured, open-ended questions were adapted in order to explore the research questions. Semi-structured questions help to cover all parts of the actions which supposed to be explored and investigated during the practices of crisis management and strategic planning. Further, open-ended questions allow the interviewees to describe or define a situation or event in a proper way (Saunders et al., 2009). The interview questions may differ according to the interviewees' backgrounds, positions, or organizational contexts, taking into consideration the research questions.

Thus, using a semi structured interviews process, seems to be more suitable for this study. The collection of data was conducted through face-to-face, visiting the respondents in their offices at work. The attendance of the researcher may bias responses in interview as claimed by (Creswell, 2009). Therefore, the researcher was much concerned to create very relaxed atmospheres during the process of data collection for example using ice breaker questions at the beginning. Further, the interview respondents were carefully selected to be able to fill in the blanks needed addressing issues not covered in the study. The selected respondents are mainly top managers of the firm and hold positions of unit heads or supervisors. The summary of the data collection for qualitative method and interviews are presented in table 2.

Table 2

Interview Elements \& Description

\begin{tabular}{|l|l|}
\hline Elements & Description \\
\hline $\begin{array}{l}\text { Case study company } \\
\text { (GEDCO) }\end{array}$ & $\begin{array}{l}\text { The central focus of this study is to evaluate the effectiveness of } \\
\text { strategic planning processes by integrating crisis management } \\
\text { into those processes in times of crises. }\end{array}$ \\
\hline $\begin{array}{l}\text { Sample location } \\
\text { Gaza Strip - Palestine }\end{array}$ & $\begin{array}{l}\text { The criteria for choosing this case study is that it is considered } \\
\text { as a representative for the service sector firms to develop } \\
\text { strategic plans for dealing with external effects. Interviewees } \\
\text { were selected based on their levels of experience, expertise and } \\
\text { knowledge in the field and practice of crisis management and } \\
\text { strategic planning. }\end{array}$ \\
\hline Sampling strategy & $\begin{array}{l}\text { The sampling method was quota technique to select the better } \\
\text { knowledgeable interviewees capable to answer questions } \\
\text { relating to the study objectives. }\end{array}$ \\
\hline Sample size & $\begin{array}{l}8 \text { participants from top management were interviewed. This } \\
\text { number is based on availability and number of people who were } \\
\text { able to answer and ready to participate. }\end{array}$ \\
\hline $\begin{array}{l}\text { Number of interviews } \\
\text { (8) and duration (30 - 40 } \\
\text { minutes). }\end{array}$ & $\begin{array}{l}\text { The interview took an average of 30-40 minutes for each } \\
\text { interview. Semi-structured interview was used and answers } \\
\text { related to the research topic as a whole were allowed. }\end{array}$ \\
\hline
\end{tabular}

Source: Adapted from Alteneiji (2015). 
MANAGEMENT SCIENCES

Vol. 11, No. 3, 2021, E-ISSN: 2225-8329 @ 2021 HRMARS

\section{Semi-structured Interviews}

The semi-structured interviews were adapted in order to explore the study questions. Semistructured questions help to cover all parts of the actions which supposed to be explored and investigated during the practical processes of the integration of crisis management and strategic planning. The interviews were conducted among 8 top managers who had 10-15 years of work experience in crisis and strategic management field inside the Gaza Electricity Distribution Company. Totally, interviews were conducted in 2 weeks with the highest positions in the company.

The interviews were conducted inside the Gaza Electricity Distribution Company (GEDCO). Initially the researcher distributed interview forms to each one of the interviewees including: position held, department/division, educational status, years of experience, purpose of this interview, topics to be covered, approximate time to be taken, confidentiality considerations, permission for video recording, interview questions, conclusion and appreciation and finally any remarks regarding the interview. Noticeably, the interview questions of the study were adapted from several authors such as (Ozcan, 2015) for crisis management variable. Alotaibi (2013) for the strategic planning. All questions were finalized and validated by experts and academics. Totally, interviews were conducted in 2 weeks with the highest positions in the company as shown below:

Table 3

List of interviewees at GEDCO, Palestine

\begin{tabular}{|c|c|c|}
\hline \multicolumn{3}{|c|}{ Gaza Electricity Distribution Company (GEDCO) } \\
\hline No. & Interviewees & Position \\
\hline 1 & A & Board of Directors \\
\hline 2 & $\mathrm{~B}$ & Board of Directors \\
\hline 3 & $\mathrm{C}$ & GM of The Company \\
\hline 4 & $\mathrm{D}$ & Senior Manager of Strategic Planning Department \\
\hline 5 & $E$ & Manager of HR Department \\
\hline 6 & $\mathrm{~F}$ & Manager of Public Relations Department \\
\hline 7 & G & Manager of Financial Department \\
\hline 8 & $\mathrm{H}$ & Manager of Corporate Communications Department \\
\hline
\end{tabular}

\section{Thematic Analysis}

The main method of analysis for the qualitative interview data in this study was thematic analysis as recommended by previous studies such as (Eppang, 2017; West, 2012). For instance, in the study of West (2012), the thematic analysis of interview data revealed that while living with chronic pain was generally a bad experience, the respondents also revealed a number of strength points, and ways of overwhelming the challenges of chronic pain that appeared clearly in the themes: Recognizing individual strength; Looking for the positives in life; Accepting the pain; and Learning to accept assistance. So finally, the study revealed the impact of chronic pain to be widespread, resulting in physical, social and emotional changes for family members. According to Braun \& Clarke (2013) thematic analysis can be used to develop a detailed descriptive explanation of a phenomenon or its features. As they claimed also that thematic analysis is a method if identifying, analyzing and reporting themes or patterns within data. 


\section{MANAGEMENT SCIENCES}

Vol. 11, No. 3, 2021, E-ISSN: 2225-8329 @ 2021 HRMARS

Thematic analysis of interview data in this study, revealed that integrating crisis management into the strategic planning process is totally a positive experience, the participants as well revealed a number of strengths and ways of overcoming the provocations of crises, classified in the themes by recognizing those crises, looking for opportunities, taking the pains and lastly, learning from crises.

\section{Results and Discussions}

\section{Demographic Details of Respondents}

This section presented the demographic information of respondents retained in the study. The specific demographic information sought in the study included the respondents' gender, education, years of experience and position obtained. The descriptive results revealed that total numbers of male and female participated in the questionnaires were 86 males and 23 females respectively which showed the majority of respondents were male, by $78.9 \%$ of the total.

In terms of educational qualification showed that the bachelor degree holders constituted the majority of the respondents ( $n=74 ; 67.9 \%)$. The second largest group comprised persons with Diploma ( $n=23 ; 21.1 \%)$. Master's degree holders made up a total of $11 \%,(n=12)$. 
INTERNATIONAL JOURNAL OF ACADEMIC RESEARCH IN ACCOUNTING, FINANCE AND MANAGEMENT SCIENCES

Vol. 11, No. 3, 2021, E-ISSN: 2225-8329 @ 2021 HRMARS

Table 4: Respondents' Demographic Profile

\begin{tabular}{|c|c|c|}
\hline Demography & Frequency & Percent \% \\
\hline \multicolumn{3}{|l|}{ GENDER } \\
\hline Male & 86 & 78.9 \\
\hline Female & 23 & 21.1 \\
\hline \multicolumn{3}{|l|}{ EDUCATION } \\
\hline Diploma level & 23 & 21.1 \\
\hline Bachelor's degree level & 74 & 67.9 \\
\hline Master's degree level & 12 & 11.0 \\
\hline \multicolumn{3}{|l|}{ YEARS Of EXPERIENCE } \\
\hline 1 - less than 3 & 18 & 16.5 \\
\hline 3 - less than 5 & 5 & 4.6 \\
\hline 5 - less than 7 & 6 & 5.5 \\
\hline 7 - less than 10 & 27 & 24.8 \\
\hline Above 10 & 53 & 48.6 \\
\hline \multicolumn{3}{|l|}{ POSITIONS } \\
\hline Manager & 18 & 16.5 \\
\hline Head of Dept. & 37 & 33.9 \\
\hline Head of Division & 12 & 11.0 \\
\hline Line Manager & 9 & 8.3 \\
\hline Supervisor & 7 & 6.4 \\
\hline Technical Engineer & 9 & 8.3 \\
\hline Accountant & 9 & 8.3 \\
\hline Secretary & 3 & 2.8 \\
\hline Admin Assistant & 5 & 4.6 \\
\hline
\end{tabular}

\section{Qualitative Analysis Procedure}

A fast glance on the practical aspect on the strategic planning process that is operated in GEDCO by the top management team and planners in the company. Thus, the steps that the top management applied for the strategic planning process included: developing vision and mission, creating goals and selecting strategies, considering the external environment using PEST analysis and internal environment using SWOT analysis to have an effective strategic planning (Mintzberg, 1998). In particular, several steps have been created to practically integrate the rapidly evolving crisis management into the strategic process, and there is a general consensus about the most important ones that include: 
MANAGEMENT SCIENCES

Vol. 11, No. 3, 2021, E-ISSN: 2225-8329 @ 2021 HRMARS

STEP 1: Analyzing the common values and experiences of staff and board to organize a meeting or a workshop to facilitate crisis management and strategic planning.

STEP 2: Reviewing and updating a Mission Statement for the firm.

STEP 3: Analyzing the firm's external environment ("PEST" - economic, social, and technological factors) and internal environment (resources or inputs, processes, and performance or outputs).

STEP 4: Conducting a SWOT analysis (assessing the firm's internal strengths and weaknesses, and its external opportunities and threats) mainly to manage crises as planned.

STEP 5: Creating small groups for more in-depth planning activities for crises that occur in main areas.

STEP 6: Reviewing the firm's existing strategic plan of the crisis to recognize aspects of the plan that are still strategic, particularly those that are no longer strategic due to changing environments and crises effects.

STEP 7: Presenting a view of where the firm should be in 3-5 years from today.

STEP 8: Identifying the strategic issues confronting by the firm.

STEP 9: Formulating goals and strategic objectives to address major crises confronting the firm and to ensure its longer term growth and sustainability.

STEP 10: Developing work plans that show particular activities, responsibility, resources needed, and indicators by which performance will be tested during and after the crisis.

STEP 11: Identifying new steps for resource recruitment and creating a financial plan costs activities and outlines approaches for generating enough revenue or funding.

STEP 12: Preparing the written five-year strategic plan (mission statement, environmental analysis, strategic problems and strategic objectives, activity plans, sustainability, financial plans, crisis plans, monitoring and assessment of procedures).

STEP 13: Seeking approval and disseminating the crisis plan to staff, stakeholders, and potential donors, using this as an opportunity to market the firm or to build useful working relationships and coalitions.

STEP 14: Implementing the plan as a base for setting performance standards, decisionmaking, planning, observing, and resources allocation.

STEP 15: Using and evaluating the crisis plan systematically, updating after two or three years if needed.

Therefore, the first sub question which is: how crisis management works in the strategic planning process in GEDCO? Was answered by showing the above steps of the strategic process in order to fulfill the objectives in confronting crises.

Accordingly, it is strongly recommended that crisis management should be integrated into the strategy process. In this context, GEDCO worked on such integration in the strategic planning process as the top management team have many more steps to assimilate some dimensions of crisis management into the strategic planning process and to be involved in the process such as: crisis proneness and crisis preparedness in terms of dealing with internal and external crises. Both of these systematic dimensions indicated to such approach which is the proactive approach as to be considered to have a successful integrated process. Therefore, crisis proneness and crisis preparedness are to be integrated into the strategic process for offering substantial advantages particularly for minimizing the possibility of crises occurrence in the company. Whereas, the second sub question which is: Who are the main influencers in the strategic process? Was answered by showing the aforementioned managers and their influence on making decision related to the company's strategic issues, internally and externally. 
MANAGEMENT SCIENCES

Vol. 11, No. 3, 2021, E-ISSN: 2225-8329 @ 2021 HRMARS

Significantly, all interviewees in the study stressed on the integration of crisis management including crisis proneness and crisis preparedness into the strategic planning process in the time of crises. This contributed to the most of the strategic processes to be effective, practical and very distinguished from any other process. Without a doubt, the respondents' confirmation was totally agreed with the recommendation of Preble (1997), adding crisis management's capability to strategic planning can produce a more comprehensive approach to the strategic planning process in firms for making strategies that deal with crises. In fact, this orientation can strongly supply firms with a defensive capability for preventing crisis growths or diminishing their effects. Another way of thinking as argued also by Vargo \& Seville (2011) about this point in the context of resilience aspect. As this aspect is considered the ability of a firm to survive and succeed, both in good times and in bad times. Basically, the conducted interviews in the study added very distinctive information on the integration of crisis management into the strategic planning process and its influence on this process in the company.

To clarify more regarding the integration, respondents determined elements to define accurately and professionally crisis management from the strategic process view as integrated strategic process in the company. Some explanations supported this view, according to the respondents' standpoints: crisis management must be integrated into the strategic planning process in the company to deal professionally and seriously with all crises, especially external ones. Importantly, scenario planning as a first step to have better integration process, should be included as a part of crisis management plan for decision making preparation process. Therefore, scenario planning is vital to develop a strategic plan. As it levels the company up from crisis-prone to crisis-prepared and gearing up for external effects. This consensus of respondents explained how and what is the best way to integrate crisis management into the strategic planning process as the best method to deal effectively with crises.

The coding of interviews conducted was done based on predetermined themes. These themes were mainly based on the study questions, reflecting on crisis management and strategic planning, attitudes toward the integration of crisis management into the strategic planning processes in the service sector firms, challenging factors, and organizational influencing factors. The coding of the interviews was performed based on predetermined themes.

\section{Crisis Management is a Part of Strategic Planning}

Some of the respondents that defined crisis management from the viewpoint of the process for more effectiveness, used particular components to describe crisis management as a creation of certain practical perspective or even how to be integrated into strategic process in the company. However, the respondent $E \& H$, had different views in this regard. Respondent E, argued that "Crisis management and its results are not final, but temporary, and therefore its treatment is also impermanent, not like strategic planning. Its characteristics differ somewhat from planning. Specially in our actual life, there is inaccuracy in information, data, and negative employee attitudes towards any plan, incorrect forecasts and assumptions, neglect of the human side, which leads to workers' opposition to the plan and obstruction to its implementation and reliance on external bodies in developing the plan and not taking into account the change in reality such as the type of economy and the financial position of the organization. Therefore, we do not consider crisis management to be part of strategic planning because it requires a lot from us. It is possible to manage the crisis without formal 
MANAGEMENT SCIENCES

Vol. 11, No. 3, 2021, E-ISSN: 2225-8329 @ 2021 HRMARS

planning for the reasons I mentioned above". On the other hand, there were many different opinions other than the two prior views regarding this issue "Standards vary according to types of crisis. Strategies are taken to cope with the crisis to be treated and dealt with such crises". Respondent A.

"First is the criterion of high efficiency for those who will lead the process of dealing with the crisis in a practical and effective manner. In other words, crisis management is an integral part of strategic planning in our company to deal professionally and seriously with all crises, especially external ones, as they are more severe to our works". Respondent A, B, C \& D.

"Use the strategic plan is needed in this case in order to apply it as a master plan to achieve our desired goals and also to serve our publics as much as possible". All in all crisis management perspective should be incorporated in the strategic process to produce a resilient and effective process that provides more strategic solutions in confronting crises internally and externally". Respondent F.

"It is so important in this case and it should be taken into consideration for those who will lead the process of coping with the crisis in an effective way. So it is recommended to achieve this efficiency, crisis management as a perspective supposed be involved into strategic planning. Therefore, we keep endeavoring to use every possible facility to keep up the good work". Respondent $\mathrm{G}$.

Table 5: Crisis management is an integral part of strategic planning

\begin{tabular}{|l|l|}
\hline $\begin{array}{l}\text { Response } \\
\text { Codes }\end{array}$ & $\begin{array}{l}\text { Crisis management is a } \\
\text { part of strategic } \\
\text { planning }\end{array}$ \\
\hline A & V \\
\hline B & V \\
\hline C & V \\
\hline D & V \\
\hline E & \\
\hline F & V \\
\hline G & V \\
\hline H & \\
\hline Total & 6 \\
\hline & \\
\hline & $75 \%$ \\
\hline
\end{tabular}

\section{Crisis Management within Strategic Planning Process in the Company}

Joining the crisis management's capacity to the strategic planning's process in service firms can produce a more broad approach to the strategic planning of the company. Thus, integrating this capability into the strategic process can give the company with a defensive competency for preventing crisis developments or lessening their effects if a crisis occurs. The process which develops strategies, can successfully take advantage of a firm internal strengths, minimize weaknesses, and confront threats that threaten the firm in order to take opportunities originating from the market environment or by the reducing or redesigning of potentially harmful products or services. Accordingly, some responses supported this approach. 
MANAGEMENT SCIENCES

Vol. 11, No. 3, 2021, E-ISSN: 2225-8329 @ 2021 HRMARS

Steps in the Strategic Planning Process

"It is notable that in our company, there are several experts or facilitators vary the sequence of these steps, but there is a consensus about the most important ones as following:

- To analyze the values of staff through meetings and workshops to facilitate strategic planning.

- $\quad$ To review, update and set a mission statement for the company.

- To investigate the company's external environment using PEST analysis: political, economic, social, and technological factors.

- To conduct a SWOT analysis (evaluating the company's internal strengths and weaknesses, and its external opportunities and threats). Stated by the member of the board (Respondent A) who was interviewed by the researcher.

"For sure, we follow several practical steps in our strategic processes in the company such as: Creating small groups for more deep planning activities in main areas. Reviewing the company's existing strategic plan to define aspects of the plan that are still strategic, those that are no longer strategic due to changing environments, and gaps that should be addressed. Improving a vision of where the company should be three to five years from today "vision of success". Defining the strategic issues facing the company. Formulating goals and strategic objectives to treat major issues facing the company and ensure its longer term growth and sustainability. Stated by the general manager (Respondent C).

"Yes,.. there is constant planning by top management to develop work plans showing specific activities, persons responsible, resources needed, and indicators by which performance will be measured. In addition to seeking the approval then distributing the plan to staff, stakeholders, and potential donors, using this as an opportunity to market the company or to build useful working relationships and coalitions. Finally using and reviewing the plan systematically, updating or revising it after two or three years, if needed. Stated by the senior manager of strategic planning department (Respondent D) and agreed by the rest of respondents who were interviewed.

Integrating Crisis Management into the Strategic Planning Process

"In our company preparing for the crisis is very essential point especially in the present unstable environment. In crisis time, it is significant to utilize crisis management in the strategic planning process in order to manage crises effectively. The result of the incorporation is that the company can prepare for crises and achieve the aspect of resilience in any strategic plan. So flexibility in this context is not only to escape peacefully but also to keep on discipline and consistency, in all times. Additionally, crisis proneness and crisis preparedness in terms of dealing with internal and external crises, are considered to be integrated into the strategic process for offering significant advantages mainly for diminishing the possibility of crises occurrence in the company. So, if crisis management is integrated into the strategic planning process as a dynamic tool, the company is enabled to shift from crisis-prone to crisis-prepared. Stated by the senior manager of strategic planning department (Respondent D) who was interviewed by the researcher.

He continued... "the outstanding role of strategic planning in times of crises and its relation to crisis management is remarkably considered. Managers constantly should be working on making crisis management as an integral pillar of strategic planning. So, managers should use a strategic approach to crisis management by embodying crisis management perspectives in the strategy process. 
MANAGEMENT SCIENCES

Vol. 11, No. 3, 2021, E-ISSN: 2225-8329 @ 2021 HRMARS

This opinion was also agreed by the other respondents that the incorporation of crisis management in the strategy process, helps developing the efficiency of managing crises and improving the strategic performance of the company. The adoption of strategic crisis planning is the typical method to integrate the two disciplines because it increases the effectiveness of managers particularly in dealing with crises. A table as shown below summarized the standpoints of the respondents in the study A, B, C, D, E, F, G \& H. All of them concluded that any strategic planning process, that does not strive for high reliability of planning and crisis management, is not a trustworthy strategic process at all.

Table 6: Crisis Management within strategic planning process

\begin{tabular}{|l|l|l|}
\hline Response Codes & $\begin{array}{l}\text { Steps in the strategic } \\
\text { planning process }\end{array}$ & $\begin{array}{l}\text { Integrating crisis management into } \\
\text { strategic planning process }\end{array}$ \\
\hline A & V & V \\
\hline B & V & V \\
\hline C & V & V \\
\hline D & V & V \\
\hline E & V & V \\
\hline F & V & V \\
\hline G & V & V \\
\hline H & V & V \\
\hline Total & 8 & 8 \\
\hline Percentage \% & $100 \%$ & $100 \%$ \\
\hline
\end{tabular}

\section{Crisis Management Integrates into the Strategic Planning Process}

Based on previous studies, crisis management is strategic in nature and it should be integrated into strategic planning process. Tony Jaques (2010) claimed that in order to help avoid such organizational crises, leaders need to integrate crisis management into the strategic planning process to make sure a no-fault environment to encourage reporting of possible failures and errors and to be prepared in order to willingly accept bad news and unusual results. According to Karam (2018), crisis management is highly recommended to be integrated into the strategic processes in firms based on the similarities between strategic planning and crisis management and the positive correlations between both constructs. In line with Jayathilake (2012), the strategic planning is positively correlated with crisis management. Thus, it is confirmed that crisis management should be a vital part of the strategic planning process that companies embrace (Evans \& Elphick, 2005). Accordingly, firms must develop crisis management and integrate it into the strategic planning process (Higley, 2006).

Supplementing to these results, some of the respondents that defined crisis management from the strategic process standpoint for more effectiveness, used particular components to describe crisis management as a creation of a certain practical perspective or even the possibility to be integrated into strategic processes in the company. Some of the explanations supporting this claim, according to the respondents' views. Such as, Respondent A when he confirmed that: "Strategies are taken to cope with the crisis to be treated and dealt with such crises systematically and strategically". So, crisis management should be integrated into the strategic planning processes in our company to deal professionally and seriously with all crises, especially external ones, as they are more severe to our works". He added significantly: 
MANAGEMENT SCIENCES

Vol. 11, No. 3, 2021, E-ISSN: 2225-8329 @ 2021 HRMARS

"scenario planning should be included as a part of crisis management plan for preparation and decision making capability.

In the context of Gaza, the existence of a positive relationship between the availability of strategic planning and crisis management in the local bodies in Gaza Governorates is highly proved and must be considered and in political situations is more required (Al Shobaki et, al., 2016). In another study in Palestine, which was conducted by Kattan et al. (2007), to investigate the effect of the crisis on strategy, it must be integrated in the strategic planning process particularly under environmental uncertainty in the context of the Israeli-Palestinian case. Therefore, this study findings indicated that there is a statistically significant correlation and positive relationship between crisis management and strategic planning processes. Consequently, the integration is important to rapidly evolving the crisis management with strategic planning.

Concerning the interviews, overall respondents agreed about considering crisis management perspective and to be integrated into the strategic planning process as they considered this integration is the best way to overcome crises internally and externally specially during the geopolitical environment. The majority of respondents stressed on this point where they certainly learned from the reality they live and experienced different types of crises on daily basis. As said by the respondent A. All of us have experienced the geopolitical problems, therefore, solving all of these problems is very hard as if it is impossible to find immediate solutions for all of these big problems. As a result, this has provided strength and high experience to the company especially to cope with crises and minimizing their effects".

All in all, the interviewees largely commented and confirmed that the adoption of crisis management must be considered to be joined with strategic planning in order to increase and boost the effectiveness of strategic process in dealing with crises in such a situation like the geopolitical environment. Basically all respondents confirmed and recommended based on their different experiences, to integrate crisis management into the strategic planning process in order to have the best strategic solutions for confronting the internal and external crises and for dealing professionally and effectively with the different challenging organizational environments. Remarkably, all of the respondents are considered main influencers, as some of them usually participate in decision making and some of them such as: A, B, C, D, E actually have the responsibility to take actions concerning the strategic planning processes in the company.

This study was conducted in a developing country and found crisis management as an effective concept is to be integrated with strategic planning process. Managers and practitioners of crisis management can play an essential role in improving different skills help in choosing the appropriate approach according to the nature of the crisis, which is equally important for strategic planning. The study explored the advantages of crisis management for experts and presented an applicable model in developing countries. Therefore, the conceptual model of this study was relevant to most of the service sector firms.

Likewise, managers should learn and practice different crisis management approaches, since previous studies found that crisis management was most effective in the service sector (Maska et al., 2017; Priporas, \& Poimenidis, 2008; Smith, 2005). That was beneficial for managers to overcome the crises and as a result, they can get great organizational success, but if they do not manage crisis proficiently, it may lead to failure. Besides, this is equally beneficial to managers to be experts in their fields and to learn how to play a role in a team in order to avoid organizational failures as well as to make a difference in their performance. 
MANAGEMENT SCIENCES

Vol. 11, No. 3, 2021, E-ISSN: 2225-8329 @ 2021 HRMARS

The major practical implication for this study was that the service sector managers should consider the significant role of strategic planning in uncertainties and its close connection to crisis management. Hence, managers in those firms should work on making crisis management as an integral part with strategic planning. GEDCO should employ crisis management perspectives to strategic planning by embodying these perspectives into the strategy process. The study promoted the integration of crisis management into a firm's strategic planning process. Promoting the adoption of strategic crisis planning was a systematic method to join the two disciplines because it increases the effectiveness of firms' managers especially in dealing with crises.

\section{Conclusion}

This paper has discussed the basic similarities in order to define an inevitable link between strategic planning and crisis management in order to provide several areas for integration opportunity. A key benefit is, adding crisis management capability for preventing crises or reducing their effects to strategic planning's focus on markets and competition to make the strategic planning process more comprehensive and effective. Moreover, there is a need for this integrated process which represents ideal training tools to bring the discussion of crisis management issues directly into the business environment of firms. Furthermore, it is expected that the direct inclusion of crisis management in strategic planning process could offer a positive motives to push forward the limitations of strategic planning and therefore contribute to the scientific progress. It should also alleviate many of the difficulties that hinder crisis management from spreading and legitimize it in the minds of firms' managers. Finally, the strategic planning process that does not strive for high consistency and crisis preparedness, is a process that is subject to failure at any time.

Theoretically, the study was successfully applied the Dynamic Capabilities Theory to come out with effective and positive findings that can be applied suitably in the context of the service sector firms. According to Baretto (2010), the dynamic capabilities perspective especially in the field of strategic management, focused on the strategy implementation that was provided by a certain resource over time to handle changing business environments. Similarly, (Teece, 2007) argued that the dynamic capabilities framework, enabled firms to renew competencies and strategically manage the internal and external organizational skills, routines and resources required to keep the strategic performance in the face of any challenging business conditions. He viewed dynamic capabilities as the firm's ability to integrate, build, and reconfigure internal and external competences to address rapidly changing environments. More significantly, this study underlined the applicability of dynamic capabilities theory in understanding how firms used dynamic capabilities to create and sustain a strategy by responding effectively to environmental changes (Teece, 2007). In brief, the findings provided additional support and added a further understanding that this theory helped firms to seize opportunities in order to successfully reallocate resources and adjust existing competencies. On the other hand, the contextual point of view confirmed that this study extended a more comprehensive understanding of what drove the level of promoting strategic planning among managers in the service sector firms. The positive direct relationship between crisis management and strategic planning has been established in the literature in different contexts (Karam, 2018; Vargo \& Seville, 2011; Pollard, \& Hotho, 2006). As well, the main practical implication for this study was that the service sector managers should consider the significant role of strategic planning in times of crises and its relation to crisis management. Managers in those firms should work on making crisis management as an integral part with 
MANAGEMENT SCIENCES

Vol. 11, No. 3, 2021, E-ISSN: 2225-8329 @ 2021 HRMARS

strategic planning as endorsed by the study respondents regarding the integration of crisis management into the the stategic planning process in the company.

\section{References}

Achampong, F. K. (2010). Integrating risk management and strategic planning. Planning for Higher Education, 38(2), 22.

Al Shobaki, M. J., Amuna, Y. M. A., \& Naser, S. S. A. (2016). Strategic and Operational Planning As Approach for Crises Management: Field Study on UNRWA. International Journal of Information Technology and Electrical Engineering. 5 (6):43- 47.

Alotaibi, H. (2013). Strategic planning: a practice perspective on strategic initiatives an applied study on Saudi telecommunication companies (Doctoral dissertation, University of Southampton).

Alsharif, A. H., Salleh, N. Z. M., \& Baharun, R. (2021a). The neural correlates of emotion in decision-making. International Journal of Academic Research in Business and Social Sciences, 11(7), 64-77.

Alsharif, A. H., Salleh, N. Z. M., \& Baharun, R. (2021c). To better understand the role of emotional processes in decision-making. International Journal of Academic Research in Economics and Management Sciences, 10(2), 49-67.

Alteneiji, H. R. (2015). A strategic approach to emergency preparedness in the UAE. (Doctoral Thesis, University of Salford).

Baretto, J. (2010). Writing the ideal paper for JOM: A new editor's perspective, Journal of Operations Management, 20(1), 1-18.

Braun, V., \& Clarke, V. (2013). Successful qualitative research: A practical guide for beginners. Sage.

Burnett, J. (1998). A strategic approach to managing crises. Public relations review, 24(4), 475488.

Bustinza, O. F., Molina, L. M., \& Arias-Aranda, D. (2010). Organizational learning and performance: Relationship between the dynamic and the operational capabilities of the firm. African Journal of Business Management, 4(18), 4067.

Creswell, J. W. (2009). Research design: Qualitative, quantitative, and mixed methods approaches. $3^{\text {rd }}$ Ed. Sage publications Inc.

Drabek, T. E., \& Hoetmer, G. J. (1991). Emergency Management: Principles and Practice for Local Government. Washington. DC: International City Management Association.

Eisenhardt, K. M., \& Martin, J. A. (2000). Dynamic capabilities: what are they?. Strategic management journal, 21(10-11), 1105-1121.

Eppang, M. B. (2017). The Relationship of Values of Certification, Professionalism, Job Satisfaction and Service Quality in Tourism Industry of South Sulawesi. (Doctoral Dissertation, Universiti Teknologi Malaysia - UTM).

Evans, N., \& Elphick, S. (2005). Models of crisis management: An evaluation of their value for strategic planning in the international travel industry. International Journal of Tourism Research, 7(3), 135-150.

Hancock, D. R., \& Algozzine, B. (2015). Doing case study research: A practical guide for beginning researchers. Teachers College Press. Columbia University.

Higley, J. (2006), "Lesson from the field: leaders must prepare", Hotel and Motel Management, Vol. 221 No. 10, p. 6. European Management Journal, 21 (3), 398-407.

Jaques, T. (2010). Reshaping crisis management: the challenge for organizational. Design Organizational Development Journal 28(1), pp 9-17. 
MANAGEMENT SCIENCES

Vol. 11, No. 3, 2021, E-ISSN: 2225-8329 ๔ 2021 HRMARS

Jayathilake, P. M. B. (2012). Risk management practices in small and medium enterprises: evidence from Sri Lanka. Risk Management, 2(7), 226-234.

Karam, M. G. (2018). The Impact of Strategic Planning on Crisis Management Styles in the 5Star Hotels. J Hotel Bus Manage, 7(171), 2169-0286.

Kattan, F., Pike, R., \& Tayles, M. (2007). Reliance on management accounting under environmental uncertainty: The case of Palestine. Journal of Accounting \& Organizational Change, 3(3), 227-249.

Kitching, J., Blackburn, R., Smallbone, D., \& Dixon, S. (2009). Business strategies and performance during difficult economic conditions. London, U.K. : Department for Business Innovation and Skills (BIS). 77 p.

MAS. (2015). Electricity Crisis in Gaza: Causes and Consequences. Final Report Round Table Discussion (10). P.O. 2426. Palestine Economic Policy Research Institute. Ramallah. Palestine.

Maska, L., Tsekeris, T., Kakas, C., \& Tsekeris, C. (2017). Measuring the Crisis Preparedness in the Pharmaceutical Sector: the case of Greece. Zbornik radova Veleucilista u Sibeniku, 3. pp. 7-18.

Mintzberg, H., Ahlstrand, B. W., \& Lampel, J. (1998). Strategy Safari: the Complete Guide Trough the Wilds of Strategic Management. London. Financial Times Prentice Hall, 392.

Mitroff, I. I., Pearson, C., \& Pauchant, T. C. (1992). Crisis management and strategic management: similarities, differences and challenges. Advances in strategic management, 8(2), 235-260.

Nickols, F. (2016). Strategy, strategic management, strategic planning and strategic thinking. Distance Consulting LLC.

Ocloo, C. E., Akaba, S., \& Worwui-Brown, D. K. (2014). Globalization and Competitiveness: Challenges of Small and Medium Enterprises (SMEs) in Accra, Ghana. International Journal of Business and Social Science, 5(4).

Ozcan, S. (2015). Key factors affecting crisis management effectiveness in the public sector (Doctoral dissertation, University of Southampton).

Pollard, D. (2008). Organizational crises and the strategic management process: evidence from transformation economies. 5th International Scientific Conference, Vilnius, Lithuania.

Pollard, D., \& Hotho, S. (2006). Crises, scenarios and the strategic management process. Management Decision, 44(6), 721-736.

Preble, J. F. (1997). Integrating the crisis management perspective into the strategic management process. Journal of Management Studies, 34(5), 769-791. Press Publishing.

Priporas, C. V., \& Poimenidis, I. (2008). Services managers' awareness of crisis management: attitudes and preparation. Innovative Marketing, 4(3), 37-45.

Saunders, M., Lewis, P., \& Thornhill, A. (2009). Research Methods for Business Students $\left(5^{\text {th }}\right.$ Ed.). India: Pearson Education Limited.

Sax, J. (2015). Strategic risk management: Analyzing antecedents and contingencies for value creation. Copenhagen Business School [Ph.D.].

Sekaran, U. (2003). Research Methods for Business (4th Ed.). Hoboken, NJ: John Wiley \& Sons.

Smith, D. (2005). Business (not) as usual: crisis management, service recovery and the vulnerability of organizations. Journal of Services Marketing, 19(5), 309-320.

Spillan, J., \& Hough, M. (2003). Crisis planning in small businesses:: Importance, Impetus and Indifference. European Management Journal, 21(3), 398-407. 
Teece, D. J. (2007). Explicating dynamic capabilities: the nature and micro foundations of (sustainable) enterprise performance. Strategic management journal, 28(13), 13191350.

Teece, D. J., Pisano, G., \& Shuen, A. (1997). Dynamic capabilities and strategic management. Strategic management journal, 509-533.

Vargo, J., \& Seville, E. (2011) 'Crisis strategic planning for SMEs: finding the silver lining. International Journal of Production Research, Vol. 49, No. 18, pp.5619-5635.

West, C. P. (2012). A mixed methods sequential explanatory study of the impact of chronic pain on family resilience. Ph.D. Thesis, James Cook University.

Yang, K., \& Banamah, A. (2014). Quota sampling as an alternative to probability sampling? An experimental study. Sociological Research Online, 19(1), 1-11.

Yin, R. K. (2013). Case study research: Design and methods. $5^{\text {th }}$ ed. Sage Publications. London. UK.

Young, R. D. (2003). Perspectives on Strategic Planning in the Public Sector. Columbia: Institute for Public Service and Policy Research, Universidad de South Carolina. 